\title{
O GOZO PRIVADO DA POLÍTICA PÚBLICA - ENFOQUE TERRITORIAL NA POLÍTICA NACIONAL DO TURISMO
}

\author{
THE PRIVATE JOY OF PUBLIC POLICY - TERRITORIAL \\ APPROACH IN NATIONAL TOURISM POLICY \\ EL GOZO PRIVADO DE LA POLÍTICA PÚBLICA - ENFOQUE \\ TERRITORIAL EN LA POLÍTICA NACIONAL DEL TURISMO
}

\author{
Rangel Lima Garcia \\ Doutorando do Programa de Pós-Graduação em Geografia da UNICAMP \\ Professor do Centro Universitário Ítalo Brasileiro \\ E-mail: rangeografia@gmail.com
}

\begin{abstract}
Resumo: A Política Nacional do Turismo e a inclusão de municípios e regióes no Mapa do Turismo Brasileiro, constitui parte de uma ação dirigida ao desenvolvimento econômico do setor. Além disso, visa orientar as tomadas de decisões de empresas e governos, nos níveis federal, estadual e municipal, no sentido de indicar investimentos e territórios de interesse para a economia do turismo. As linhas de ação da Política Nacional do Turismo do governo de Michel Temer precisam ser divulgadas e analisadas. $\mathrm{O}$ objetivo deste texto é contribuir nesse sentido, analisando as implicaçóes para o futuro do País. Apoiando-se nos estudos de Rita Cruz (2005) e Ruy Moreira (1985 e 2006), o que se identifica, acerca da produção do espaço e do arranjo espacial brasileiro, resultado desse processo, é que as políticas públicas do turismo, alinhadas às açóes e ao planejamento governamental, agravam ainda mais os quadros de concentração de riqueza e de desigualdades sociais e regionais. Questiona-se ainda, os resultados desse conjunto articulado de açóes para a dinâmica dos negócios imobiliários no Brasil.
\end{abstract}

Palavras-chave: Brasil. Mapa do Turismo. Política Pública. Turismo. Desigualdades.

Abstract: The National Tourism Policy and the Inclusion of Municipalities and Regions in the Brazilian Tourism Map, is part of an action aimed at the economic development of the sector. Besides that, it aims to guide the decision making of companies and governments, at the federal, state and municipal levels, to indicate investments and territories of interest to the tourism economy. The lines of action in the National Tourism Policy of the government of Michel Temer needs to be divulged and analyzed. The objective of this text is to contribute in this sense, analyzing the implications for the future of the country. Based on the studies of Rita Cruz (2005) and Ruy Moreira (1985 and 2006), what is identified about 
the production of space and the Brazilian space arrangement, the result of this process, is that the public policies of tourism, aligned the actions and the governmental planning, further aggravate the concentration of wealth and social and regional inequalities. It is also questioned the results of this articulated set of actions for the dynamics of real estate business in Brazil.

Keywords: Brazil. Tourism Map. Public Policy. Tourism. Inequalities.

Resumen: La Política Nacional del Turismo y la inclusión de municipios y regiones en el Mapa del Turismo Brasileño, forma parte de una acción dirigida al desarrollo económico del sector. Además, pretende orientar las tomas de decisiones de empresas y gobiernos, a los niveles federal, estatal y municipal, en el sentido de indicar inversiones y territorios de interés para la economía del turismo. Las líneas de acción de la Política Nacional del Turismo del gobierno de Michel Temer precisan ser divulgadas y analizadas. El objetivo de este texto es contribuir en ese sentido, analizando las implicaciones para el futuro del país. Apoyándose en los estudios de Rita Cruz (2005) y Ruy Moreira (1985 y 2006), lo que se identifica, acerca de la producción del espacio y del arreglo espacial brasileño, resultado de ese proceso, es que las políticas públicas del turismo, alineadas a las acciones y al planeamiento gubernamental, agravan aún más los cuadros de concentración de riqueza y de desigualdades sociales y regionales. Se cuestiona, además, los resultados de ese conjunto articulado de acciones para la dinámica de los negocios inmobiliarios en Brasil.

Palabras Clave: Brasil. Mapa del Turismo. Política Pública. Turismo. Las Desigualdades.

\section{INTRODUÇÁO}

Uma primeira versão deste texto foi produzida durante os meses de maio e junho de 2017, com o objetivo de ser publicado nos Anais do Encontro Nacional dos Pós-graduandos em Geografia, realizado em outubro do mesmo ano, na cidade de Porto Alegre/RS. Fatos alheios a nossa vontade impossibilitou a publicação naquele momento. Assim, o retomamos neste ano de 2018, e o dirigimos à Revista Entre-Lugar, Revista do Programa de PósGraduação em Geografia da UFGD.

A principal motivação para a produção desse texto, veio do conjunto de leituras e debates promovidos na disciplina Turismo e produção do espaço ${ }^{1}$. O tema aqui abordado trata das recentes políticas públicas e linhas de ação estatal relacionadas a pasta do Turismo. Nelas, se destaca o enfoque territorial e regional, destinado aos investimentos públicos e privados. $\mathrm{O}$ mesmo é manifesto no conteúdo dos documentos oficiais de planejamento do setor há pelo menos duas décadas, segundo levantamento de Rita Cruz (2005). É, nesse mesmo contexto, que se insere o "Mapa do Turismo Brasileiro" (BRASIL, 2013b, 2016 e 2017a), denominado de MAPA neste artigo, bem como o Programa BRASIL + TURISMO (BRASIL, 2017b), entre outros planos de ação dirigidos ao desenvolvimento do setor na gestão de Michel

1 Turismo e produção do espaço é o nome da disciplina ministrada pela Profa. Dra. Rita de Cassia Ariza da Cruz, do Programa de Pós-Graduação em Geografia da USP, no primeiro semestre de 2017. 
Temer. Apoiando-se, sobretudo nos trabalhos de Rita Cruz (2005) e Ruy Moreira (1985 e 2006), focou-se no enfoque territorial das políticas públicas para o desenvolvimento da análise, buscando trazer as implicações atuais e futuras ao país.

Para tanto, selecionou-se alguns aspectos dos planos da pasta do Turismo, lançados no momento em que Michel Temer, após golpe institucional2 ${ }^{2}$ sofrido por Dilma Rousseff, assume a presidência da república. Contudo, fez-se uma breve caracterização e uma análise da forma como se tem aplicado a Política Nacional do Turismo, tomando como principal referência o MAPA e o enfoque territorial de tal política pública. O MAPA é um instrumento de ação estatal que envolve seleçấo, diferenciação e classificação de territórios e regióes. Além dessa política do Turismo, o enfoque territorial é destacadamente presente no movimento de realizaçáo das políticas públicas cujo objetivo indica o tema do desenvolvimento econômico. E dela se busca partir para cumprir o que aqui se intenta.

O objetivo principal deste trabalho é contribuir com as análises que se faz do futuro do País, principalmente àquelas que tratam das políticas do Turismo. É também objetivo deste trabalho divulgar e analisar as Políticas Públicas do setor implementadas recentemente, sobretudo no governo interino de Michel Temer. É ainda, objetivo importante deste trabalho, iniciar um cruzamento de parte da teoria de Ruy Moreira (1985 e 2006) com as análises focadas na economia e nas políticas de Turismo.

A metodologia empregada para se alcançar os objetivos traçados é basicamente a da investigação documental e bibliográfica. Buscou-se identificar, selecionar e entrecruzar o conteúdo dos documentos e publicaçóes oficias, com as que se selecionou de referencial da Geografia e áreas afins. O trabalho partiu do levantamento daquilo que é mister ao setor, ou seja, do MAPA, feito com fins de orientar as tomadas de decisão de empresas e governos, nos níveis federal, estadual e municipal, sobretudo no sentido de indicar investimentos e territórios de interesse para a economia do turismo. Daí, partiu-se para uma contextualizaçáo do MAPA diante do enfoque territorial das políticas públicas, desaguando na divulgação dos planos e programas lançados por Michel Temer. Por fim, buscou-se analisar as implicaçōes do conjunto para o futuro do País, apoiando-se nos estudos de Rita Cruz (2005) e Ruy Moreira (1985 e 2006).

A importância que o setor do Turismo vem adquirindo no âmbito das políticas públicas e dos investimentos no Brasil, bem como sua complexidade diante dos reflexos que causa para um sem número de outras atividades direta e indiretamente relacionadas, estão muito bem contextualizadas no artigo Clara C. Lemos (2013). Além disso, a autora descreve e analisa o organograma de funcionamento institucional do Turismo no Brasil, apresentando funçôes, alcances e limites dos diferentes órgãos estatais e de composição mista (estatal e privado). Mostra também a posição de destaque do Ministério do Turismo frente às demandas do setor, cujo planejamento de açóes está atrelado à Lei Geral do Turismo, à Política Nacional do Turismo, ao Plano Plurianual e à Lei Orçamentaria Anual (LEMOS, 2013).

Outro texto que serve de referência e estímulo a este trabalho é o de Christiano Henrique

2 Segundo o júri do Tribunal Internacional Sobre a Democracia no Brasil. Disponível em: $<$ http://www.redebrasilatual.com. br/politica/2016/07/impeachment-de-dilma-e-golpe-de-estado-decide-tribunal-internacional-2792.html>. Acesso em: 19 jun. 2018.. 
da Silva Maranhão (2017). Nele se apresenta o percurso histórico da institucionalização do Turismo no Brasil, nascido com a Divisão do Turismo nos anos de 1939, a fim de controlar a entrada e a saída de estrangeiros no Brasil. A análise avança até os dias atuais, destacando os ocorridos nas décadas de 1980, 1990 e 2000. Segundo o autor, depois de passar por 10 diferentes órgãos estatais, diante da complexidade que o setor do Turismo apresenta, é no ano de 2003 que o Turismo se institucionaliza enquanto Ministério de Estado. A partir daí, destaca os planos e programas criados com o intuito de fomentar a atividade do Turismo no País, sintetizando o conjunto em um didático quadro interpretativo (MARANHÃO, 2017, p. 253). O autor conclui a análise destacando:

[...] que quando a visão econômica limita à compreensão do turismo, enquanto fenômeno, ela acaba fazendo com que as açóes promovidas pelo poder público ratifiquem os hiatos sociais já existentes no país, contrariando a ideia tão difundida nos discursos políticos que tratam do turismo, como uma possibilidade de minimizar desigualdades regionais (MARANHÃO, 2017, p. 257).

\section{ENFOQUE TERRITORIAL NA POLÍTICA NACIONAL DO TURISMO}

\section{O MAPA E AS POLÍTICAS PÚBLICAS DE ENFOQUE TERRITORIAL}

Um componente importante do MAPA é que dele apenas fazem parte municípios que se adequam aos requisitos definidos pela "Categorização dos Municípios das Regióes Turísticas". Nesse sistema de categorizaçáo, criado para subsidiar as tomadas de decisáo relacionadas aos investimentos no setor, incluem-se os municípios direta e indiretamente ligados a economia do turismo. Segundo os documentos oficiais (BRASIL, 2018), são aqueles que possuem estabelecimentos de hospedagem e recebem turistas internacionais e domésticos, bem como os municípios fornecedores de insumos para aqueles que recebem visitantes e possuem serviço de hospedagem. Contudo, vale destacar que o município fora do sistema de "categorizaçáo" fica excluso do MAPA, e assim, impedido de receber investimentos provenientes ou capitaneados pelo Ministério do Turismo, denominado de MTur neste artigo.

O MAPA, e nele a inclusão e a categorização de Municípios e regióes, revela o enfoque territorial de base para a sustentação do conjunto das políticas nacionais de desenvolvimento no Brasil, e também da atividade econômica do turismo. Os documentos oficiais reveladores desse enfoque, bem como do conjunto das linhas de ação com fins de se "diminuir desigualdades sociais e regionais", são fruto de um planejamento estatal orquestrado preteritamente, e que se vê em pleno exercício neste século XXI.

Há muitos estudos reveladores desse aspecto, e um deles se apresenta na dissertação de mestrado de GARCIA, 2012. Nela, se analisa um longo trabalho de referência sobre o Brasil, organizado pelo Ministério do Planejamento, Orçamento e Gestão, o ESTUDO DA DIMENSÃO TERRITORIAL PARA O PLANEJAMENTO (BRASIL, 2008). Tanto na dissertação, quanto no decorrer deste texto, o referido trabalho denomina-se ESTUDO. $\mathrm{O}$ texto de apresentação geral do ESTUDO declarava a que veio: 
O Estudo da Dimensão Territorial para o Planejamento pretendeu não apenas analisar a profunda imbricação entre desenvolvimento e território, mas também propor, a partir daquela análise, um conjunto articulado de investimentos capazes de provocar uma modificação na configuração atual do território nacional. [...] Sob esse ponto de vista, pode-se afirmar que o Estudo possui como pressuposto que os investimentos do Governo, particularmente do Governo Federal, são determinantes de uma nova geografia econômica do Brasil (BRASIL, 2008). ${ }^{3}$

O ESTUDO possui oito Volumes e sete deles estão disponíveis para consulta e download. A exceção é o Volume com as bases de georreferenciamento, indisponível desde o lançamento do ESTUDO ${ }^{4}$. No total são cerca de 1.300 páginas, e todo levantamento deságua na apresentação de uma "Carteira de Investimentos" que, "teoricamente, conduzirão o Brasil à superação das desigualdades sociais e regionais".

O ESTUDO apresenta uma leitura do território nacional, pautada sobretudo nas suas "homogeneidades/heterogeneidades" bem como na influência dos pólos urbanos, configuradas em uma cartografia de forma e escala bem definidas. Todos os mapas aparecem na pequena escala, tanto os que buscam caracterizar o território, bem como os que indicam as localizaçóes e as regióes estratégicas das pretensas açóes da esfera federal do planejamento. Vale expor parte desta cartografia (vide FIGURA 1), e na sequência a seleção de passagens do texto do ESTUDO, minimamente esclarecedores:
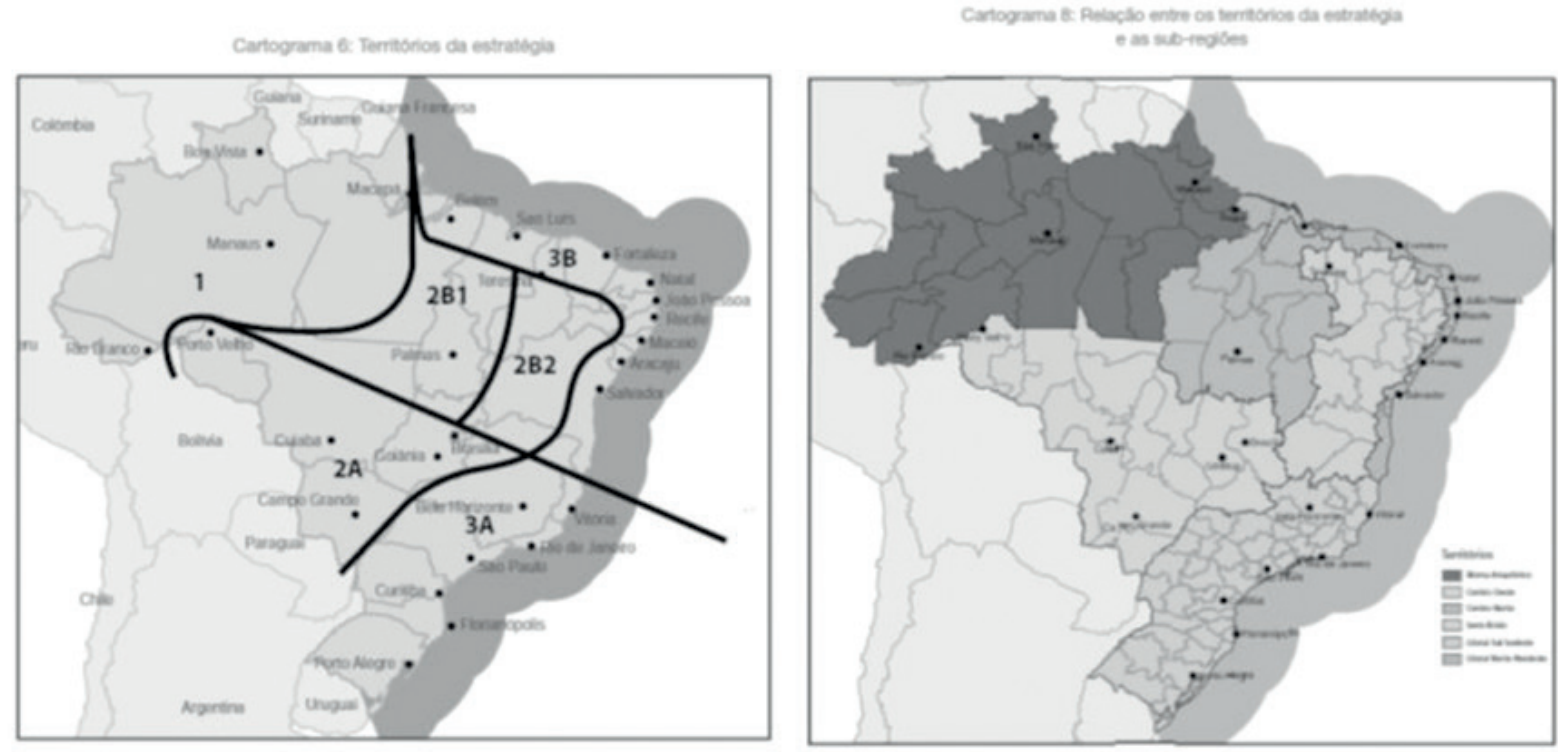

Figura 1 - Cartografia representativa do Brasil no ESTUDO: "Cartograma 6: territórios da estratégia" e "Cartograma 8: Relação entre os territórios da estratégia e as sub-regiões" (Brasil, 2008, Vol. II, P. 54 e 59, respectivamente).

3 O trecho citado é parte da apresentação do documento no site do Ministério do Planejamento, disponível em: $\leq$ http://www. mp.gov.br/secretaria.asp?cat=156\&sub=181\&sec=10>. Acesso em: 01 jul. 2010.

4 O download dos sete volumes do ESTUDO 2008 está disponível em: < http://bibliotecadigital.seplan.planejamento.gov.br/ handle/iditem/404>. Acesso em: 22 jun. 2018. 
A visão estratégica nacional ancorada no território, que parte dos seis territórios propostos no item anterior, denominados Territórios da Estratégia, é compatível com as escalas das regióes de referência do Estudo, em especial com a sub-regional (118 sub-regióes), e destas com a macrorregional (11 macrorregióes).

$[\ldots]$

Os seis territórios, que não são regióes em si, guardam relação com a compreensão dos traços de homogeneidade/heterogeneidade que organizam o mapa brasileiro. As 11 macrorregiôes e as 118 sub-regiōes dizem respeito a uma outra tradiçáo teórica, fundada na polarização urbana, crucial para discutir o comando efetivo sobre o território. O cruzamento dessas duas tradiçóes ajuda a desvendar nexos fundamentais do território em direção à construção de estratégias de desenvolvimento (Vol. II, BRASIL, 2008, p. 58).

Ambos os mapas, mostram o território nacional em escala apropriada para se visualizar os Estados Nacionais vizinhos, bem como a divisão interna na forma das Unidades Federativas. No primeiro deles, observamos alguns pontos pretos que destacam as capitais estaduais e a capital federal Brasília. Além disso, observa-se, em linha grossa e preta, uma divisão do território denominada de "estratégica". Sáo seis territórios delimitados a partir das cidades polo de influência, das "homogeneidades" internas, e "heterogeneidades" em relação aos demais. No segundo mapa, há o ajuste dessas linhas dos seis "territórios da estratégia” em relação aos limites municipais, agrupados nas denominadas "sub-regioes".

Os porquês da constituição de tais "sub-regióes" se apresenta no Volume III do ESTUDO, intitulado de "Regióes de Referência". Nele se construiu uma regionalização em duas escalas (sub-regional e macrorregional), ambas agrupando territórios dos municípios. No ESTUDO, afirma-se que

Foram considerados critérios econômicos, ambientais e sociopolíticos na definição dessas regióes, que têm em conta o papel desempenhado pelas cidades na organização do território, dada a força de polarização em sua área de influência (BRASIL, 2008, Vol. III, p. 14).

Segundo o documento, tal divisão regional permite subsidiar a escolha e a localização de projetos de investimentos, bem como a articulação de políticas públicas. Contudo, observa-se na leitura do documento, uma dupla significaçáo do conceito de regiáo, uma primeira no sentido do reconhecimento das regiôes a partir das "homogeneidades/ heterogeneidades", e uma segunda no sentido de funcionalidade territorial, ou seja, que tipo de uso do território pode e deve ser feito nessas regióes.

Os chamados "territórios da estratégia" dão lugar às "regióes de referência", num movimento semelhante de ressignificação que também identificamos no MAPA e nas políticas de desenvolvimento do turismo. Um arcabouço teórico e metodológico aplicado às necessidades do planejamento, das açóes e da estratégia estatal do investimento público e privado, validando a categoria "regiáo" nos moldes como Ruy Moreira a indica, ou seja, "modos de estratégia e não modos geográficos de ser, eis em suma o que hoje é a regiáo como categoria de organização das relações de espaço" (2006, p. 166). 
Além disso, o projeto de país publicado no ESTUDO indica uma "linha de ação" principal: a formulação de uma "Carteira de Investimentos". Em um primeiro estágio, apontam-se investimentos públicos no setor de infraestrutura de energia e de transporte. Num segundo movimento, o documento aponta a necessidade do investimento privado, ambos dirigidos às "regióes economicamente mais frágeis" e ao mesmo tempo "mais promissoras do território nacional” (BRASIL, 2008, Vol. V, p. 53). É nesse ponto da estratégia, planejada há dez anos atrás que se encaixam os planos atuais do Turismo, no governo de Michel Temer. $\mathrm{O}$ leitor vai perceber esta ligação ao encontrar, mais a frente, as consideraçóes sobre a Portaria Interministerial no 113, lançada em maio de 2017.

Retomando o ESTUDO, fica evidente que os investimentos nele propostos, se projetam numa "escala nacional", num plano de religação do todo territorial regional-nacional a partir da rede de cidades e de estruturas de circulação, comunicação e deslocamento, intra e inter-regionais, compreendendo: estruturas de produção, de deslocamento e alojamento de informaçóes, mercadorias, energia e pessoas.

A pasta do turismo sugere o que deve ser investido em cada regiáo turística do MAPA, e deixa claro que é este o seu fim, como mostraremos no decorrer deste artigo. Esse aspecto de promover e destinar lugares ao investimento, identificado tanto no ESTUDO quanto no MAPA que agora procuramos analisar, culmina no processo de territorialização que, na visão de Ruy Moreira (1985), implica considerar o que há de universal (imperialismo) em cada particular processo de formaçáo econômico-social (o Brasil). Isto significa dizer que o capitalismo se "mundializa" a partir de aspectos fundamentais à sua realização, sobretudo nos territórios onde particularmente se realiza. Nossa análise identifica o Turismo, enquanto atividade econômica, representante desse processo de mundialização e, portanto, potencialmente atuante no modo como tal setor se territorializa no País.

Segundo Ruy Moreira (2011, p. 40), um desses aspectos universais, e que se aplica às particularidades de cada formação econômica social, refere-se às "leis espaciais do capital", a saber: a "Lei da Renda Diferencial I" (LRD-I); a "Lei da Renda Diferencial II" (LRD-II); e, a "lei espacial dos rendimentos decrescentes". Essas "leis espaciais do capital" se aplicam no processo de territorialização brasileira, principalmente pelo modo particular como agora o capitalismo se "internaliza” (MOREIRA, 1985), e também pela via do turismo.

A LRD-I “indica valorizaçáo por motivo de proximidade/ aproximação do eixo que interliga fertilidade e estruturas de circulação". A LRD-II "indica valorização por motivo de proximidade/aproximaçáo do eixo seguinte ao da LRD-I, pois esgotados os limites dos fatores de produção, fertilidade e estruturas, parte-se para o eixo da inovação/ complementação tecnológica" (MOREIRA, 2011, p. 40). Assim, a inclusão de lugares na dinâmica de valoração se dá via (re)estruturação das redes de circulação entre lugares, ou seja, através da construção das redes de transporte, de comunicação e de energia.

A busca pela melhor localização nessa rede de estruturas de interligação de lugares torna-se fator preponderante na estratégia de qualquer negócio, e isso também se aplica às estratégias relacionadas ao Turismo. Esse processo se amplia diante do atual estágio de internalização do capitalismo no Brasil e sua realização leva investidores, estabelecimentos 
produtivos, agentes financeiros, e trabalhadores expropriados, tanto da terra quanto dos meios de produção, seja no campo seja na cidade, à busca pela melhor localização. Esse movimento simultâneo de disputa por territórios, diante do contexto e dos planos de ação governamental do Turismo, reforça a importância do MAPA.

Retomamos essa breve análise para nela inserir outros contextos da produção do MAPA, foco da análise neste texto, pois se coloca como linha de ação estatal, a fim de servir de base para a formulação de políticas públicas e de investimentos. Para tanto, se faz necessário retomar parte dos debates e discussóes com os colegas na disciplina Turismo e produção do espaço, já citada no início deste artigo. $\mathrm{O}$ destaque refere-se ao modo como a atividade do turismo está, e atua, na produçáo do espaço, num processo social, histórico, conflituoso e contraditório.

O persistente contexto de "desigualdades sociais e regionais" marcam o território nacional, já identificado como "realidade histórica e estruturalmente concebida, expropriadora, excludente e espacialmente seletiva, típica do modo de produção a que estamos todos submetidos" (CRUZ, 2005, p. 35). Além de Rita Cruz, soma-se as contribuiçóes de Ana Fani Alessandri Carlos (2011), num conjunto de passagens que se combinam e se complementam mutuamente com o que se selecionou de Ruy Moreira. Trabalhou-se esse cruzamento referencial mais cuidadosamente na tese, em construção. Por ora, se apresenta algumas passagens de suporte à análise, onde no conjunto compartilha-se da ideia de que

[...] a produção do espaço em seu novo sentido - no processo de valorizaçáo do valor - inscreve-se e realiza-se na contradição entre espaços integrados e desintegrados em relação ao movimento de reprodução do capital como desdobramento da contradição centro-periferia. $\mathrm{O}$ mundial esmaga e coage as relaçóes nos lugares desintegrados em relação à lógica da reprodução global.

Portanto, trata-se no momento histórico em que a existência generalizada da propriedade privada reorienta e organiza o uso do lugar. Momento também em que o espaço-mercadoria se propóe para a sociedade enquanto valor de troca destituindo-o de seu valor de uso e, nessa condição, subjugando o uso, que é condição e meio da realização da vida social, às necessidades da reprodução da acumulação como imposição para a reprodução social. É exatamente nesse momento que a extensão da propriedade se realiza plenamente, ganhando novos contornos, através da produçấo do espaço enquanto mercadoria e produzindo novas contradições. Neste período da história, realiza-se socialmente, por meio da apropriação privada, a lógica do valor de troca sobre o valor de uso que está no fundamento dos conflitos tanto no campo quanto na cidade (CARLOS, 2011, p. 67).

Recorre-se à passagem acima no sentido de dar base teórica à reflexão que se sucede. Primeiro, associa-se o conjunto ao que é universal no capitalismo segundo Ruy Moreira (1985). A dinâmica de atribuir valor de troca em detrimento do valor de uso, remete a um processo contínuo, e cada vez mais intenso, de inclusão de lugares nesse mundo do espaço-mercadoria. $\mathrm{O}$ uso do espaço enquanto mercadoria se dinamiza e se amplifica na medida em que se mundializa. 
O turismo, nas suas mais variadas formas de ação e participação na produção do espaço, e na transformação deste em mercadoria de seu próprio negócio, potencializa o que Ruy Moreira (2011, p. 40) reapresenta na forma das "leis espaciais" de valoração e de desvaloração dos lugares. O turismo reforça esse caráter do espaço enquanto mercadoria, cujo valor faz um sobe e desce comandado e operado, pelas mesmas mãos que dele detém o controle e a posse proprietária.

No atual contexto das políticas públicas de fomento da atividade turística, esse processo de produçáo do espaço, configurador do arranjo espacial brasileiro, tende a se agravar. Mais ainda, diante do perfil político-econômico neoliberal assentado nas cadeiras do executivo nacional, agora sob o comando do MDBista Michel Temer. Cabe divulgar e analisar alguns de seus movimentos. A hipótese aqui, é a de que as açóes e estratégias de fomento do turismo no Brasil, a partir de maio de 2016, agravam ainda mais o caráter expropriatório e excludente já identificado. Vejamos.

\section{O PROGRAMA BRASIL + TURISMO}

O Programa BRASIL + TURISMO (BRASIL, 2017b) exige o debate, principalmente diante do conjunto de Portarias e Projetos de Lei que propóe. O alagoano e ex-prefeito de Coruripe, Max Beltrão, assumiu a pasta sob a indicação de Michel Temer. Em abril de 2017, lançou o Programa que visa o estímulo ao setor do turismo na forma de um conjunto de medidas. As principais são:

- Melhor aproveitamento dos terrenos da União;

- Abertura para capital 100\% estrangeiro na exploração dos serviços aéreos;

- Concessão de vistos eletrônicos para turistas de principais países emissores;

- Programas de "Qualificação Profissional padrão exportação";

- Melhorias no ambiente de negócios, incluindo a inovação e a desburocratização através do conteúdo da "Lei Geral do Turismo";

- Promoção da criação das "Áreas Especiais de Interesse Turístico", numa proposta de alteração da Lei 6.513/1997;

- Inclusão de outros 14 objetivos ao Plano Nacional do Turismo, dentre eles "o fomento à pesquisa e a produção científica no turismo", a fim de se "gerar subsídios para elaboração e implementação de políticas públicas do setor”; e, o

- Fortalecimento das 291 regióes turísticas do atual MAPA, considerado "instrumento de referência para definição de políticas públicas e destinação de investimentos para o setor".

Como se vê, o enfoque territorial e regional é fundante no conjunto de medidas do Programa e, nele, o MAPA se coloca como instrumento de referência principal para a definição e a aplicação das políticas públicas.

O grande volume de informaçóes a se analisar exigiu um considerável recorte. Assim, 
selecionamos tratar de alguns aspectos do MAPA, bem como de algumas medidas específicas relacionadas ao Programa BRASIL + TURISMO. Vejamos.

\section{O MAPA E O PROGRAMA DE REGIONALIZAÇÁO DO TURISMO}

O Mapa é o instrumento instituído no âmbito do Programa de Regionalização do Turismo e que orienta a atuação do Ministério do Turismo no desenvolvimento das políticas públicas. É o Mapa do Turismo Brasileiro que define a área - o recorte territorial - que deve ser trabalhada prioritariamente pelo Ministério (BRASIL, 2016).

Segundo o MTur, os municípios que compóem o MAPA “entendem o turismo como atividade estratégica” e atendem os critérios específicos para dele fazer parte. É necessário que o município possua secretaria ou órgão específico de Turismo, dotação orçamentária prevista e aprovada pela Câmara Municipal, bem como pelo órgão de Governança Regional, o qual deve ser criado para o conjunto de municípios que se inserem em uma mesma "Regiáo Turística". Além disso, municípios e a correspondente Região devem ter "vocação turística ou ser impactados pelo setor de viagem", segundo o vídeo de divulgação do MAPA".

O MAPA de 2016 possui 2.175 Municípios, agrupados em 291 Regiōes Turísticas. Neste ano de 2018, saiu a publicação da versão do MAPA de 2017, também disponível para download ${ }^{6}$. A versão mais recente do MAPA é digital, e pode ser acessado através do site do MTur ${ }^{7}$.

Hoje, o MAPA é de conteúdo interativo, num ambiente computacional que permite a criação de mapas tematicamente mais específicos. O sistema permite a seleção e a interação de diferentes informaçóes, sendo elas: os Municípios categorizados; as Regióes Turísticas; as Unidades Federativas; e, as Macrorregióes (Norte, Nordeste, Sudeste, Centro-Oeste e Sul). Além disso, é possível gerar relatórios comparativos dos dados da "Categorização" entre 2013 e 2016.

Os municípios do MAPA se enquadram numa seletiva e burocrática "categorização", feita a partir de dados oficiais sobre a existência de empregos e estabelecimentos formais de hospedagem, e sobre a estimativa de receber turistas nacionais e internacionais. A Cartilha de Perguntas e Respostas sobre a Categorização, produzida pelo MTur, ajuda a entender melhor essa seleçáo (BRASIL, 2018). A partir desses dados e da metodologia de clusters (agrupamento por semelhança de dados), os municípios se inserem em uma das cinco categorias (A, B, C, D ou E).

5 Disponível em: $<$ https://www.youtube.com/ watch?v=JuSBs71BbBw\&index=10\&list=PLVPdAWYF0WOwHpSzECFgpcJRzieZONFNy>. Acesso em: 13 jun. 2017.

6 Disponível em: <http://www.regionalizacao.turismo.gov.br/images/pdf/mtur_mapa turismo brasilei_2017 virtual_14_02.pdf>. Acesso em: 30 jun. 2018.

7 Disponível em: $<$ http://mapa.turismo.gov.br/mapa/init.html\#/home>. Acesso em: 14 jun. 2017. 


\begin{tabular}{|c|c|c|c|c|c|c|}
\hline \multirow{2}{*}{ Categoria } & \multirow{2}{*}{$\begin{array}{c}N^{\circ} \text { de } \\
\text { Municípios }\end{array}$} & $\begin{array}{c}\text { Municípios } \\
\text { do Mapa }\end{array}$ & $\begin{array}{c}N^{\circ} \text { de } \\
\text { empregos } \\
\text { formas de } \\
\text { hospedagem }\end{array}$ & $\begin{array}{c}\text { Qnt. } \\
\text { estabelecimentos } \\
\text { formais de } \\
\text { hospedagem }\end{array}$ & $\begin{array}{c}\text { Estimativa } \\
\text { de turistas } \\
\text { internacionais }\end{array}$ & $\begin{array}{c}\text { Estimativa } \\
\text { de turistas } \\
\text { domésticos }\end{array}$ \\
\hline A & 57 & $1,74 \%$ & 2.414 & 135 & 143.926 & 1.637 .556 \\
\hline B & 179 & $5,45 \%$ & 354 & 33 & 7.561 & 215.534 \\
\hline C & 539 & $16,41 \%$ & 81 & 10 & 974 & 50.990 \\
\hline D & 1961 & $59,70 \%$ & 9 & 2 & 116 & 9.764 \\
\hline E & 549 & $16,71 \%$ & 0 & 0 & 0 & 0 \\
\hline
\end{tabular}

Figura 2: tabela com o total de Municípios por categorias do MAPA (BRASIL, 2018, p.5)

Hoje, as Unidades Federativas têm a responsabilidade de cadastrar e atualizar as informações dos municípios para a composição do MAPA, ficando o MTur com a função de sistematizar e publicar os dados. A atualização é programada para acontecer de dois em dois anos. Entretanto, houve uma atualização antecipada em um ano na gestão da pasta sob o governo de Michel Temer. O MAPA recebeu acréscimo de 1.090 municípios, perfazendo agora um total de 3.285 no Mapa de 2017. De 291 Regióes Turísticas, agora se vê 328, 37 a mais que a versão anterior ${ }^{8}$. As Figuras 3 e 4 , posicionadas a seguir, ilustram esses números em relação as Unidades Federativas.

8 O Mapa do Turismo de 2017 já está disponível para consulta e download em: <http://www.regionalizacao.turismo.gov.br/ images/pdf/mtur_mapa_turismo_brasilei_2017_virtual_14_02.pdf >. Acesso em: 22 jun. 2018. 


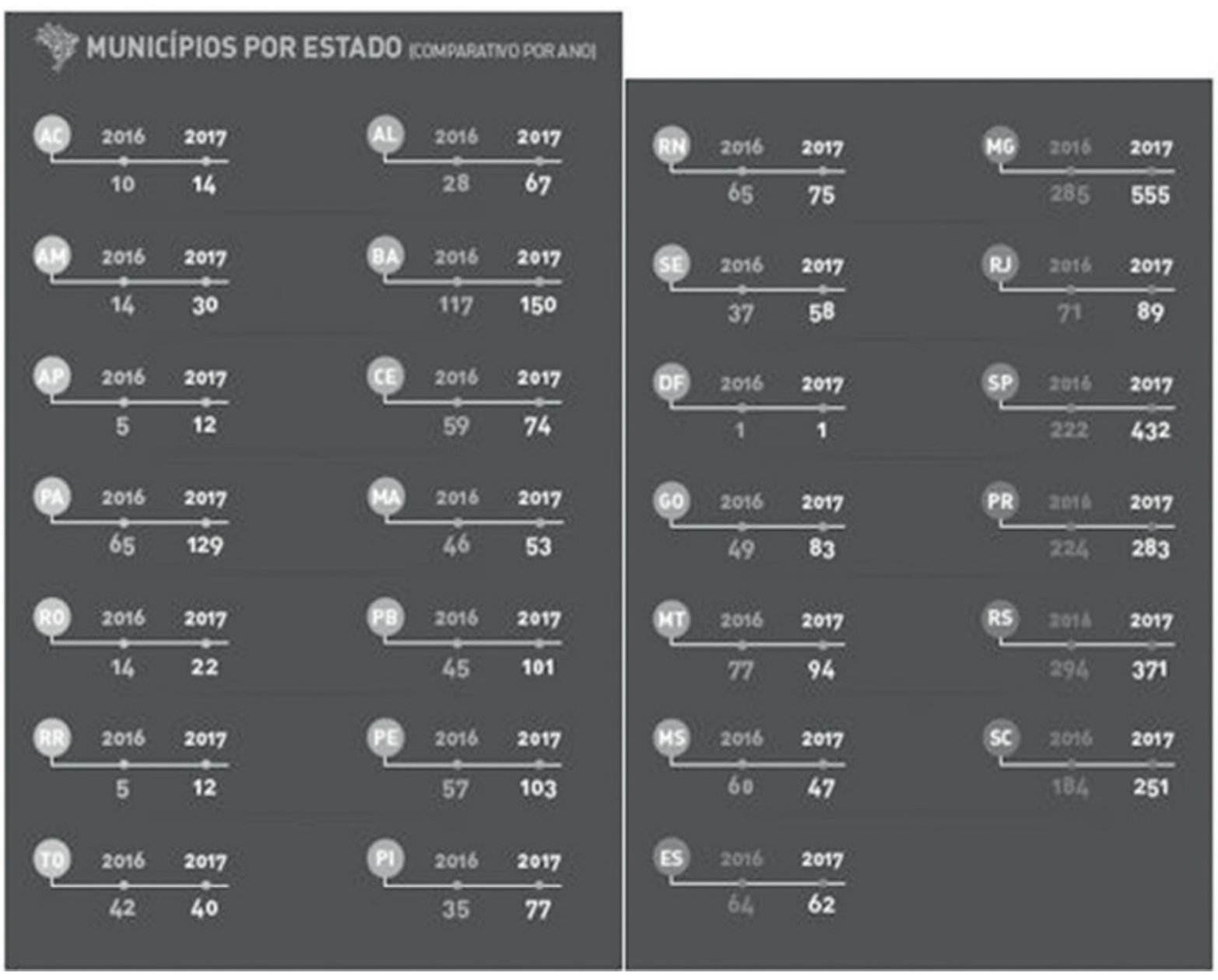

Figura 3 - Número de Municípios por Unidade Federativas, na versões de 2016 e 2017 do MAPA (BRASIL, 2017, p. 12 e 13).

Contudo, o importante para qualquer município é estar no MAPA. Somente nele posicionado é que se tem acesso aos recursos políticos e monetários distribuídos pelo MTur. A Figura 3 ilustra quão significativo foi o acréscimo de municípios, exceto nos Estados de Tocantins, Mato Grosso do Sul e Espírito Santo, onde se vê a diminuição no número de municípios. Fica para futuros estudos os casos desses Estados em que, na contramáo dos demais, houve redução de municípios inclusos no MAPA de 2017.

Nas demais Unidades Federativas, a inclusão foi expressiva. Não é o foco aqui avaliar os casos de cada Estado, mas sim destacar o crescimento de quase 50\% no número de municípios na escala nacional.

No caso das Regióes Turísticas observa-se que, das 37 novas Regiōes Turísticas, 30 surgiram na Macrorregião Sudeste, 23 somente em São Paulo. Também não será agora que buscaremos as razóes desse expressivo e concentrado crescimento, fica aí outro ponto a ser estudado no futuro. 


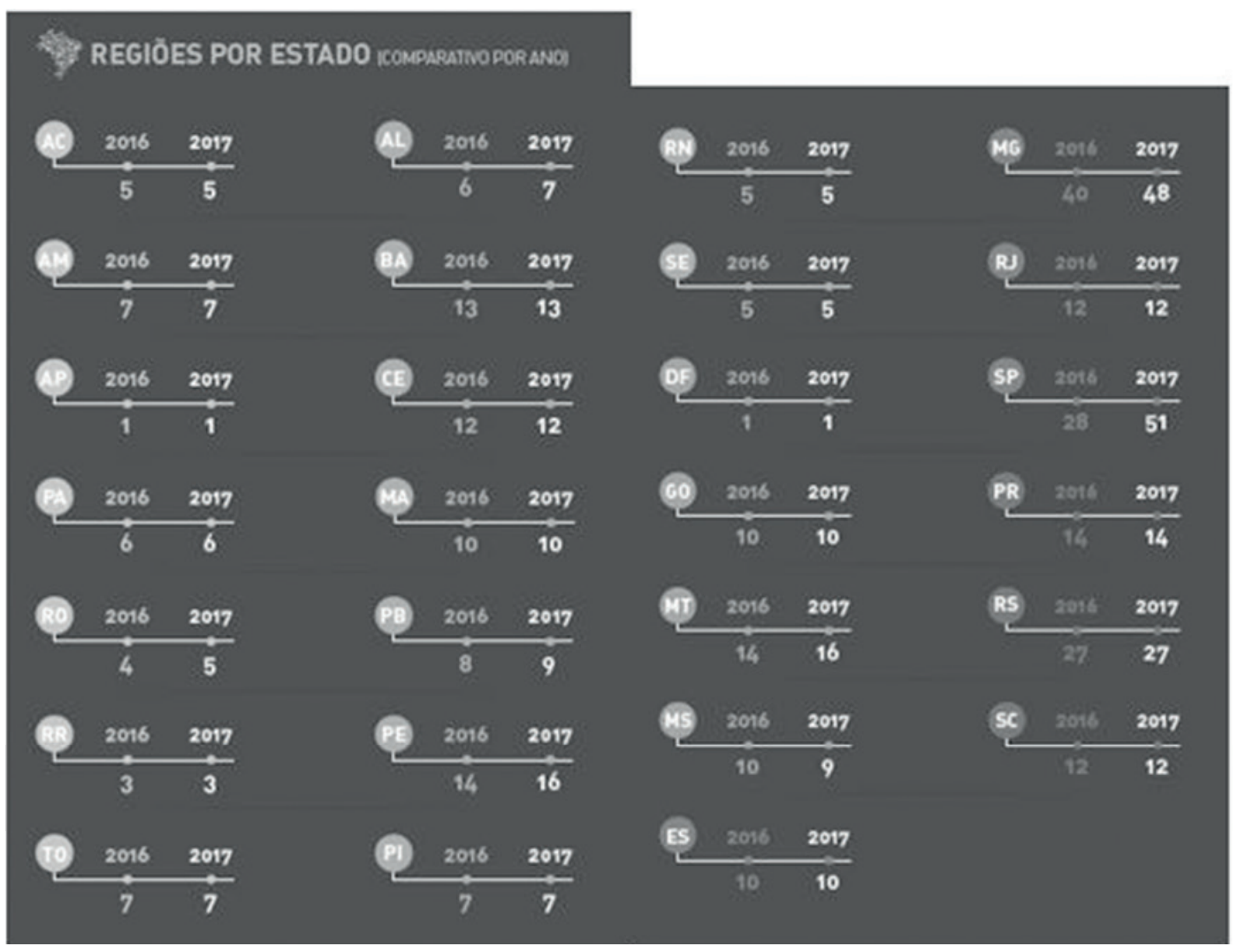

Figura 4 - Número de Regiões Turísticas por Unidades Federativas, nas verões de 2016 e 2017 do MAPA (BRASIL, 2017, p. 12 e 13).

Vimos que, para os municípios, estar no MAPA passa a ser a chave tanto para se receber aporte financeiro dos programas governamentais de turismo, quanto para atrair investimentos públicos e privados, ao território municipal e a regiáo turística da qual faz parte. Há, nos detalhes que definem a requisição e a chegada de recursos, o que caberá ou não a cada município conforme a sua categoria. Ou seja, investimentos, políticas, recursos e ações específicas serão dirigidas aos municípios conforme suas características econômicas em relação ao Turismo.

Deve-se destacar que o MAPA é uma política do Programa de Regionalização do Turismo e, segundo o MTur, "o trabalho regionalizado permite, assim, ganhos não só para o município que recebe o visitante, mas para toda a região”. No site do MTur, se esclarece que

Embasando-se em recomendaçôes da Organização Mundial do Turismo, o Ministério do Turismo adotou em 2004 essa política focada no desenvolvimento regional, dando maior protagonismo às Unidades da Federação. O Programa de Regionalização do Turismo trabalha a convergência e a interação de todas as açôes desempenhadas pelo MTur com estados, regióes e municípios brasileiros. Seu 
objetivo principal é o de apoiar a estruturação dos destinos, a gestão e a promoção do turismo no País?.

O trecho evidencia que tal política é recomendação da OMT, organismo internacional do setor ligado às demandas do capital internacional, representado pelos diplomatas de seus respectivos Estados Nacionais signatários à organizaçáo. Ainda no interior do texto explicativo do Programa, dentro do site do MTur, pode-se conhecer as suas "Estratégias de Atuação" (FIGURA 5), dado que reforça a ação regionalizadora ${ }^{10}$.

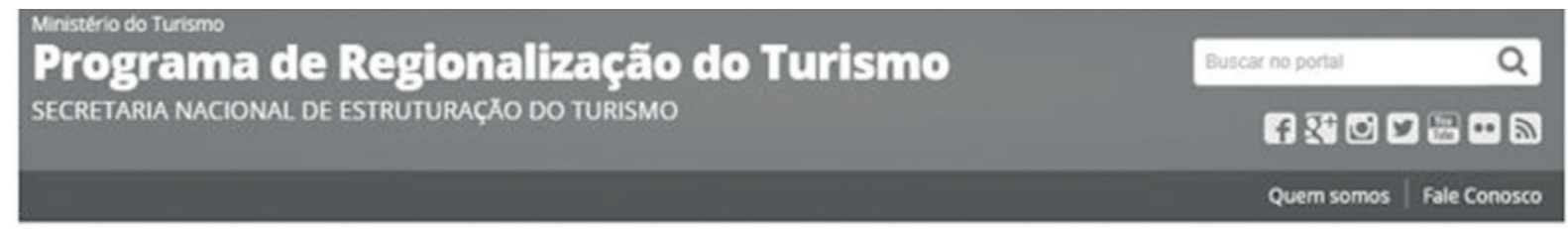

PHGMA INCCAL > PROGRAMA DE REGICNULZZACLIO DO TURISMO > ESTRATEGAS DE ATUACLC

\section{Problemas com o Mapa? \\ Reclame Aquil}

O que é o Programa de Regionalizaçào do Turismo?

\begin{tabular}{l}
\hline Assuntos \\
\hline Aprograma de \\
Regionalizaçăo do \\
Turismo \\
Exos de Atuaça \\
Estrategias de \\
Atuaşa \\
Diretrizes \\
interiocutores
\end{tabular}

\section{Estratégias de Atuação}

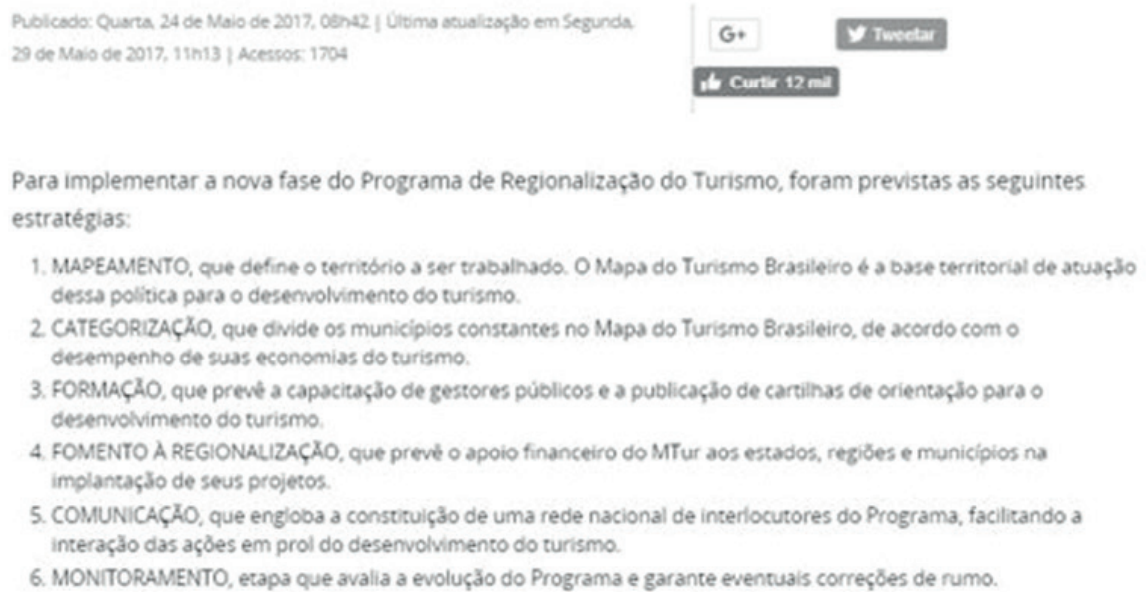

Para implementar a nova fase do Programa de Regionalizaçao do Turismo, foram previstas as seguintes estratégias:

1. MAPEAMENTO, que define o território a ser trabalnado. O Mapa do Turismo Brasileiro é a base territorial de atuaça dessa politica para o desenvolvimento do turismo.

2. CATEGORIZAÇÃO, que divide os municipios constantes no Mapa do Turismo Brasileiro, de acordo com o desempenho de suas economias do turismo

3. FORMAÇAO, que prevé a capacitaça de gestores públicos e a publicą̧a de cartilnas de orientaça para o desenvolvimento do turismo

4. FOMENTO A REGIONALIZAÇAO, que prevé O apoio financeiro do MTur aOs estados, regióes e municipios na implantaço de seus projetos.

5. COMUNICAÇĀO, que engloba a constituiçăo de uma rede nacional de interlocutores do Programa, facilitando a interaçăo das açðes em prol do desenvolvimento do turismo.

6. MONTTORAMENTO, etapa que avalia a evoluçăo do Programa e garante eventuais correçסеes de rumo.

Figura 5: Estratégias de Atuação do Programa de Regionalização do Turismo operadas pelo executivo nacional do MTur (ver nota 14)

A implementação de políticas públicas recomendadas por organismos internacionais, nos remete aos modos como o capitalismo se internaliza no território nacional, segundo Ruy Moreira (1985) e, portanto, num movimento de territorialização orquestrado através do planejamento de estado, como se pode constatar ao analisar o ESTUDO (GARCIA, 2012).

9 Disponível em: $<$ http://www.regionalizacao.turismo.gov.br/index.php?option=com content\&view=article\&id=77\&Itemid=107>. Acesso em: 30 jun. 2018.

10 Disponível em: $<$ http://www.regionalizacao.turismo.gov.br/index.php?option=com content\&view=article\&id=79\&Itemid=261 $>$. Acesso em: 30 jun. 2018. 
Além da amarração das recomendações internacionais em torno do enfoque territorial e regional, há também, por parte do executivo do MTur, uma atuação orquestrada de aproximação com instituiçóes públicas e empresas de outros setores estratégicos, como os de Inovação, Tecnologia e Meios de Transporte.

$\mathrm{Na}$ necessidade de encerrar essa parte da análise, retoma-se o apontamento sobre o significado do conceito de regiấo, já apresentado na Introdução desse texto. $\mathrm{O}$ enfoque territorial e regional das políticas públicas, inclinadas a direcionar os investimentos públicos e privados, confirma a categoria "região" nos moldes como Ruy Moreira (2006, p. 166) nos mostrara, ou seja, "modos de estratégia e não modos geográficos de ser, eis em suma o que hoje é a região como categoria de organização das relações de espaço”.

\section{O GOZO PRIVADO DA POLÍTICA PÚBLICA}

É preciso retomar as medidas principais do Programa BRASIL + TURISMO (2017b), já citado neste artigo. Selecionamos o primeiro, que indica se fazer "melhor aproveitamento dos terrenos da Uniáo", para lançar as seguintes questóes: como será feito esse melhor aproveitamento dos terrenos da União? Há propostas do atual executivo nacional nesse sentido? A resposta para a segunda questão é sim, e buscou-se pelo menos uma das proposiçóes do MTur nesse sentido, inclusive para tentar responder a primeira questáo colocada.

Vale destacar duas Portarias publicadas nos meses de março e maio de 2017 no Diário Oficial da Uniáo' no 39 e no 113, respectivamente (BRASIL, 2017c e 2017d). O conteúdo dessas Portarias propulsiona as transformaçóes e a produção do espaço nos moldes do que já fora apontado na Introdução deste artigo, segundo Ana Fani Alessandri Carlos (2011).

A primeira Portaria no 39, entre muitas outras atribulaçóes, trata da alteração da natureza jurídica da EMBRATUR (Instituto Brasileiro de Turismo) e prevê a criação da "Nova Embratur". A segunda, de no 113, refere-se mais diretamente ao modo como se dará uma "melhor utilização aos terrenos da Uniāo", proposição do Programa BRASIL + TURISMO, a fim de legitimar a "entrega" de terras da União ao MTur.

\section{PORTARIA No 39 E A NOVA EMBRATUR}

Na Portaria no 39 (BRASIL, 2017c), encontra-se o Projeto de Lei (PL) para a constituição da "Nova Embratur - Agência Brasileira de Promoção do Turismo". O PL prevê a alteração da natureza jurídica da EMBRATUR (Instituto Brasileiro de Turismo), a qual deixaria de ser autarquia para assumir a forma de "serviço social autônomo, na forma de pessoa jurídica de direito privado sem fins lucrativos". Assim, seria subsidiada por recursos "da arrecadação bruta dos prêmios das loterias federais, além de recursos transferidos de dotaçóes consignadas nos Orçamento Fiscal e da Seguridade Social". Segundo o documento, a Nova Embratur tem o objetivo principal "de formular, implementar e executar açóes de promoção comercial de produtos, serviços e destinos turísticos brasileiros no exterior, em cooperação com a administração pública federal". A Nova Embratur se enquadra no regime das instituiçôes do "sistema S". 
O “sistema S" é um termo para denominar

[...] o conjunto de organizaçóes das entidades corporativas voltadas para o treinamento profissional, assistência social, consultoria, pesquisa e assistência técnica, que além de terem seu nome iniciado com a letra $\mathrm{S}$, têm raízes comuns e características organizacionais similares (Senado Federal) ${ }^{11}$.

Essa mesma Portaria, aponta a alteraçáo a respeito da definiçãa de quem pode solicitar recursos junto ao MTur. Agora, além das Unidades Federativas, do Distrito Federal e dos Municípios categorizados e inclusos no MAPA, incluiu-se as Universidades Públicas e as organizações e instituiçóes do chamado "sistema S" e, portanto, a própria Nova Embratur.

Esse movimento articulado de transformação da natureza jurídica da Embratur expropria a Uniáo do domínio de informaçóes estratégicas para a economia do turismo e, consequentemente, do País. Trata-se de um Instituto dotado de informaçóes altamente estratégicas para o futuro das atividades econômicas do turismo, e que ficarão à mercê de quem cuidará da Nova empresa. Sob nossa análise, o que poderia e deveria ser usado para contribuir à diminuição das desigualdades sociais e regionais, dirige-se a um processo produtor de seu agravamento.

Tal análise apoia-se nos apontamentos do trabalho de Rita Cruz (2005), à respeito do modo como, sobretudo após a criação do MTur em 2003, o Estado se consolida como principal "indutor" do processo de desenvolvimento do setor, sob a justificativa neoliberal de desenvolver assim a economia do país. Em concordância com autora supracitada, questiona-se o resultado de tal política, pois é a economia de um importante setor econômico em favor de grupos hegemônicos, ou seja, em favor de parcela diminuta das pessoas físicas e jurídicas, nacional e internacional.

Pelo menos até este início do mês julho de 2018, a EMBRATUR se mantém autarquia estatal. Michel Temer garantiu a transformação da EMBRATUR em agência, em abril de $2017^{12}$. O mesmo ainda não se efetivou, mas é forte a movimentação da sua equipe executiva para a aprovaçáo do PL previsto na Portaria no 39. Outra notícia, publicada em 29 de junho de $2018^{13}$, mostra o encontro de assessores e da presidente da EMBRATUR, Teté Bezerra, com o secretário-geral da Organização Mundial do Turismo em Madrid. A figura abaixo retrata parte da notícia, confirmando os movimentos políticos em prol da alteração da natureza jurídica da EMBRATUR.

11 Disponível no site do Senado Federal: <http://www12.senado.leg.br/noticias/glossario-legislativo/sistema-s $>$. Acesso em: 07 jun. 2017.

12 Notícia veiculada em 15 de abril de 2017, disponível em: <http://www.embratur.gov.br/piembratur-new/opencms/ salaImprensa/noticias/arquivos/Temer_garante_transformacao_da_Embratur_em_Agencia.html>. Acesso em: 04 jul. 2018.

13 Disponível em: <http://www.embratur.gov.br/piembratur-new/opencms/salaImprensa/noticias/arquivos/Presidente da Embratur_se_reune_com_OMT_e_Turespana_em_Madri.html>. Acesso em: 04 jul. 2018. 


\section{Presidente da Embratur se reúne com OMT e Turespaña, em Madri}

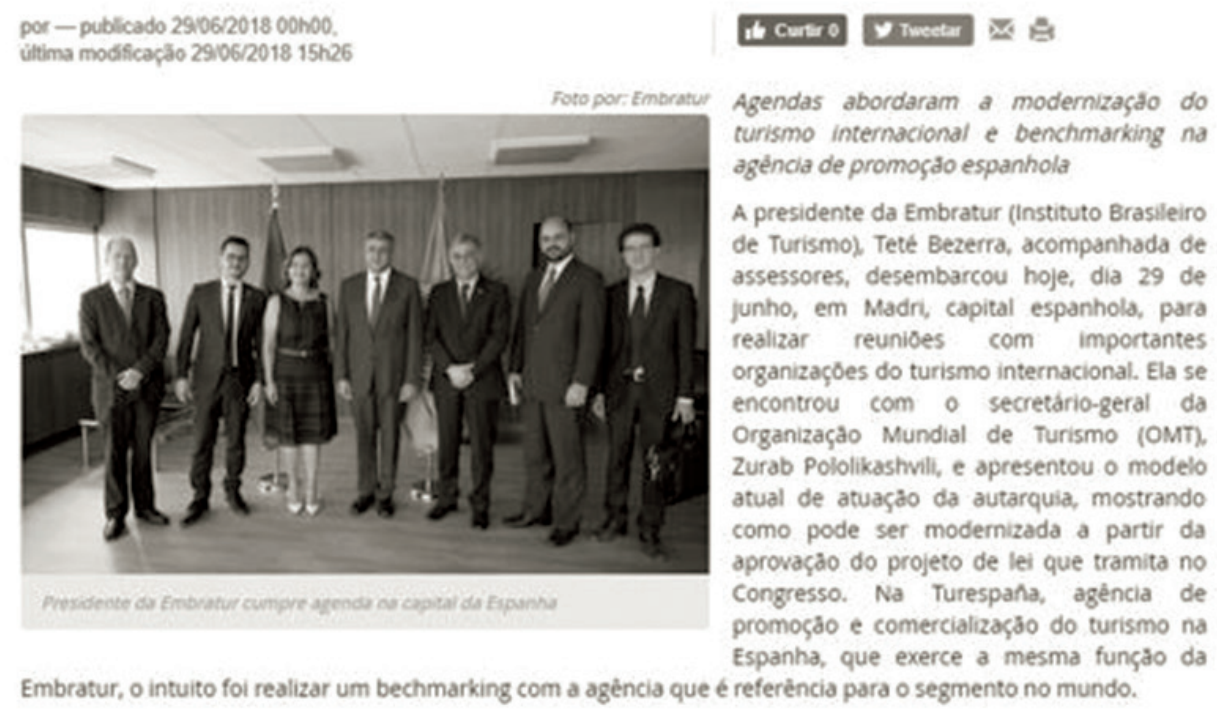

Encontro na OMT

Na sede da Organizaçăo Mundial de Turismo, em Madri, na reuniăo entre a Embratur e o órgå internacional, a presidente Teté Bezerra apresentou o plano de modernizaçao do Instituto, e a importancia da aprovaçao do projeto de lei, que faz com que a autarquia ganhe maior autonomia, tornando-se um serviço social autônomo. "Estamos, junto ao nosso Congresso, buscando a aprovaça do projeto que moderniza a atuaçăo da Embratur. Precisamos garantir que o nosso Pais esteja em patamares competitivos perante o mercado internacional", declarou.
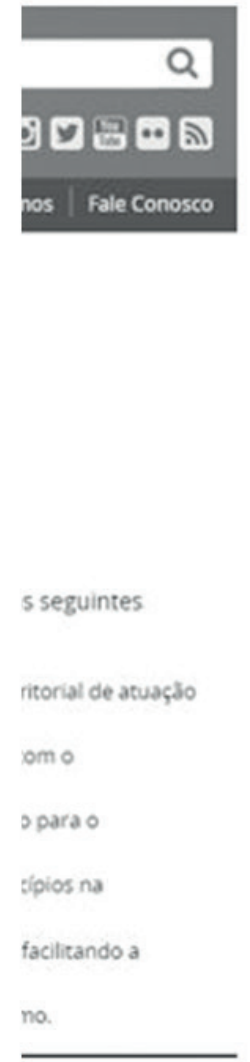

Figura 6: Notícia, publicada no site do MTur (ver nota 19), revela o comprometimento da equipe de Michel Temer em Transformar a autarquia em serviço social autônomo, diante do secretário-geral da OMT, em Madrid.

Em simultâneo, encontramos um processo licitatório para a construção do edifício sede da EMBRATUR, em terreno localizado na capital federal Brasília/DF. O "Chamamento Público" ${ }^{14}$ data deste ano de 2018 , e o processo pode ser acompanhado pelo próprio site da autarquia, na sessão "Dados Abertos"15. Contudo, pode-se aventar a hipótese de que, antes de votar o PL que sustenta a alteração da natureza jurídica da EMABRATUR, primeiro, serão definidos prazos, responsáveis e quem vai pagar a conta da construção do prédio da "Nova Embratur", segundo garantias do próprio presidente da república.

É uma situação vexatória empenhada pela equipe de governo de Michel Temer, pois falando claramente, o dinheiro público será utilizado para a construção de um prédio, que será sede de uma empresa de serviço social autônomo. Como se náo bastasse, os futuros

14 Chamamento Público para construção do Prédio da EMBRATUR disponível em: <http://www.embratur.gov.br/ piembratur-new/opencms/dados abertos/feiras/Edital-de-Chamamento-Publico-01.pdf>. Acesso em: 05 jul. 2018.

15 O acompanhamento do processo de construção do prédio da EMBRATUR está disponível em: < http://www. embratur.gov.br/piembratur-new/opencms/dados abertos/index.html>. Acesso 05 jul. 2018. 
administradores e gestores da "Nova Embratur" terão informações altamente estratégicas acerca da atividade econômica do turismo no Brasil, um riquíssimo banco de dados para investidores, como é o caso do MAPA.

\section{PORTARIA No 113 - ENTREGA E USO TURÍSTICO DAS TERRAS DA UNIÁO}

Citemos agora a Portaria Interministerial no 113 (BRASIL 2017d), publicada no Diário Oficial da União no 86, de maio de 2017. Nela, os "MINISTROS DE ESTADO DO PLANEJAMENTO, DESENVOLVIMENTO E GESTÁO e DO TURISMO, [...] resolvem: "

Art. $1^{\circ} \mathrm{O}$ Ministério do Planejamento, Desenvolvimento e Gestão, por intermédio da Secretaria do Patrimônio da União - SPU, efetuará a entrega ao Ministério do Turismo, [...] das áreas de domínio da União, ainda que não incorporadas ao seu patrimônio, localizadas em áreas com potencial para o desenvolvimento do turismo.

Art. $4^{\circ} \mathrm{O}$ Ministério do Turismo fica autorizado a promover a cessão gratuita ou onerosa das áreas recebidas através de entrega em razão desta Portaria, para a consecução dos objetivos nela previstos.

É por meio desta Portaria Interministerial que se resolve entregar, para a atividade do turismo, o "mais promissor conjunto das terras" da Uniáo ao MTur. Daí retomamos o questionamento: Esse é o modo como o Programa BRASIL + TURISMO promoverá o "melhor aproveitamento dos terrenos da União"?

Destinando a terra da maneira como descrito na Portaria, pode-se dizer, resumidamente, que o MTur identifica e seleciona as terras de maior interesse para o Turismo; as solicita frente as Superintendências Estaduais de Patrimônio da União; ambas as partes preenchem a documentação necessária para a entrega das terras, seguindo o modelo já indicado na Portaria; e, realizado o trâmite, o MTur posteriormente decide, pela entrega, pela concessáo ou pela comercialização das terras adquiridas junto à União.

Diante de tais condiçóes de entrega das terras, a inclusão dos territórios municipais no MAPA ganha ainda mais importância. A Regionalização do Turismo, e nela o MAPA, podem ser usadas como justificativa, por parte do MTur, para a indicação das áreas de interesse turístico. Ou seja, hoje, a linha de ação estratégica promovida pela Portaria no 113, pode atingir terrenos da União localizados em mais da metade dos municípios do País, precisamente em 3.285 deles. Apenas se faz necessário que o MTur identifique as áreas cuja propriedade é da União, dentro dos municípios inclusos no MAPA, pois são cabíveis do processo de entrega ao MTur.

Outra interessante relação que pode ser feita, e que depende de um futuro estudo específico, é o cruzamento das cartografias do ESTUDO com o MAPA. Nesse cruzamento 
cartográfico, poder-se-ia constatar os territórios dos municípios altamente estratégicos para os investimentos, considerando os trabalhos do planejamento estatal de 2008 e o atual.

Se faz necessário retomar as consideraçóes de Rita Cruz (2005) acerca dos "territórios negligenciados" e de Ruy Moreira (1985) com relação as "leis espaciais" de (des)valoração do espaço.

Explorando o contexto das políticas públicas de turismo no Brasil, Rita Cruz (2005) nos apresenta o "território usado" como aquele resultante das escolhas políticas cujo enfoque é o uso turístico do espaço. Mais a frente, complementa:

[...] o que também não é difícil de se apreender é que tais escolhas resultam, na prática, no uso, mas também no negligenciamento do território, em duplo sentido: de um lado, enquanto se prioriza os territórios eleitos pelo turismo com obras e normalizações de uso, se negligencia outras porçôes de território, não raras vezes abandonadas à própria sorte. De outro, os territórios usados pelo turismo são, também, paradoxalmente negligenciados, pois o que é usado é o seu potencial passível de exploração pelo turismo e negligenciada, simultaneamente, a sua condição primeira de lugar da reprodução da vida. (2005, p. 39)

É notável essa negligência em favor do mercado, o que ainda se reforça ao trazer o trabalho de Ruy Moreira (2011) para a análise. A relação entre "as leis espaciais dos rendimentos decrescentes", bem como as leis de "rendimento diferencial", inflam ainda mais o poder da especulação imobiliária e o processo de (des)valoração das terras.

Primeiro porque, no caso da atividade econômica do turismo, o próprio espaço vira mercadoria, ele é o produto consumido na atividade. Estar diante de um atrativo turístico, é estar diante de um lugar com tendência de valorização. Mais ainda quando os órgãos do planejamento de estado o colocam em destaque num MAPA, a serviço justamente da promoçáo da atividade turística e, portanto, do uso turístico do território.

O mesmo vale para lugares que ficam no trajeto ou que servem de apoio àqueles que recebem os turistas. Primeiro porque estão no MAPA. Depois, por possuir menos ou nenhum atrativo, menos ou nenhuma estrutura, pode vir a sofrer maior pressão e especulação sobre o preço da terra. Inicialmente, por apresentar frágeis condiçóes para o atendimento do setor, em relação as áreas vizinhas, vive a desvaloração do preço do espaço, numa associação à "lei espacial dos rendimentos decrescentes" (MOREIRA, 2011, p. 40). Somente num passo seguinte o terreno ganha valor no mercado, e isso pode levar um tempo cuja precisão cronológica depende da posse e da análise de informaçóes do planejamento estratégico governamental e empresarial. Estamos diante de uma hipótese, cujo alcance deste artigo não permite confirmar.

Entretanto, quanto melhor for a estrutura no entorno ou nos eixos de ligação dessa rede de lugares de interesse da atividade do turismo, maior tende a ser o valor do preço do espaço, diante da "LRD II" (MOREIRA, 2011, p. 40), ou seja, o valor tende a se elevar em relação à vizinhança, diante da proximidade da estrutura de engenharia que abriga. Isso, até o momento em que se atinge o patamar mais elevado no jogo de valoração entre os lugares, retomando o processo de desvaloração do preço, ou seja, a retomada da "lei dos rendimentos decrescentes" no lugar. 
Essa correlação entre as "leis espaciais" e a dinâmica de sobe e desce do valor do preço do espaço, diante da dinâmica da atividade do turismo, merece análise em separado. Deixamos aqui apenas essa pequena amostra do que se tem a explorar nesse universo da relação entre prática e teoria, e que envolve a categoria espaço diante do Turismo.

A princípio, todo terreno ou área com potencial de uso turístico, ou localizado nas proximidades de, tende a se valorizar. Entretanto, em se valendo do MAPA e do modo como se aplicam as suas atribuiçóes acerca dos investimentos, bem como da entrega das terras da União ao MTur, o jogo de (des)valoração pode mudar muito. Fica aqui um ponto a ser estudado no futuro, indicando já uma das implicaçóes do próprio momento em que se insere o MAPA.

O contexto geral da Política Nacional do Turismo nos indica que serão esses os lugares que receberão os investimentos e as melhorias estruturais. Saber e poder participar da construção desse futuro que se materializará nas proximidades e nas "Áreas Especiais de Interesse Turístico", é fundamental. Rita Cruz (2005) já destaca, que

Como não há turismo sem deslocamento, um dos focos centrais da ação pública federal sobre o território nos últimos anos tem sido, justamente, a ampliação e a modernização da rede de transportes nas áreas prioritárias para o desenvolvimento do turismo. Daí falarmos em velhos e novos sistemas de engenharia, velhas e novas açôes e no papel do Estado na organizaçáo do espaço para o turismo, por meio de políticas públicas e de seus respectivos diplomas legais (2005, p. 31).

As alianças políticas são acordos, formais ou não, mas sempre decisivos, entre pessoas físicas e jurídicas, públicas e privadas, que são determinantes à tomada de decisão em relação ao modo como acontece o investimento público e privado nos territórios. Todos, em teoria, têm o direito. Entretanto, poucos sabem, se organizam e se envolvem, e assim, o interesse particular prevalece na realização das obras e das políticas públicas. Para a parte final deste texto destaca-se, o que Rita Cruz (2005) já nos alertara em suas análises, que é o fato de:

[...] que a atividade econômica do turismo tem algo de inerentemente perverso na sua natureza:

1. Somente faz turismo quem tem condições para isto; assim sendo, o turismo expressa didaticamente as diferenças sociais entre indivíduos e grupos de indivíduos;

2. Se o capital é essencialmente seletivo do ponto de vista espacial, o capital atrelado ao setor turismo o é de forma ainda mais evidente, já que é o espaço o seu principal objeto de consumo;

3. O turismo elege para o seu acontecer, porçóes de espaço cujas vantagens comparativas são maiores frente a outras possibilidades espaciais. (2005, p. 38)

Uma breve correlação desse contexto, com o movimento de conjunto das linhas de ação estatal neste século XXI, permite reafirmar que o curso da Política Nacional do Turismo conduz ao agravamento das "desigualdades sociais e regionais", de renda e de oportunidades no 
Brasil. Caso o Congresso Nacional aprove esse novo formato da EMBRATUR e o conjunto das medidas do Programa BRASIL + TURISMO, veremos o agravamento dos quadros de concentração da riqueza, de expropriação da terra e dos meios de produção, que há séculos aguçam os conflitos no campo e na cidade.

O conjunto, fortalece a tese de que no Brasil prevalece o sistema onde a terra é um grande negócio, que tem o seu valor apoiado na troca, no jogo de compra e venda (GARCIA, 2015), tanto no campo quanto na cidade, potencializados pela dinâmica da atividade econômica do turismo. Contudo, e em paralelo à crise política que vivemos, o MTur é a expressão dos interesses hegemônicos mais diversos, por propor e defender a entrega das terras públicas ao uso privado da economia do turismo.

O fim dessa reflexão apenas remete a necessidade de futuros estudos, buscando indicar caminhos novos de investigação, sobretudo no que tange a transformação da geografia econômica do País a partir do Turismo.

\section{CONSIDERAÇÓES FINAIS}

Os diversos planos e programas analisados revelam o esforço governamental para a implementação de políticas públicas que se destinam a desenvolver o turismo no Brasil, e não necessariamente o Brasil.

Considerando a confirmação dos planos de ação do MTur sob o governo de Michel Temer, se têm o seguinte: o Brasil prepara o MAPA com os territórios estratégicos e devidamente "categorizados", e o entrega, junto com as terras da União, ao MTur. Daí a "Nova Embratur", de posse dos dados e informaçôes estratégicas acerca dos territórios de interesse e da economia do turismo, seleciona lugares e setores para gestar os investimentos. Posteriormente, solicita recursos do próprio MTur, bem como dos bancos públicos e privados, nacionais e internacionais, com fins de executar, os próprios projetos de estrutura, de melhorias, de qualificação profissional e de fomento da atividade, necessárias ao desenvolvimento do turismo no Brasil. Este é, diante do atual contexto das políticas públicas do Turismo, parte do que antevemos do futuro do Brasil.

O MAPA nos permite afirmar que o caráter estratégico da localização dos lugares, do e no território nacional, tem importância renovada e elevada. No campo e na cidade, o valor do preço da terra sobe e desce, num movimento de ascendência de médio e longo prazo.

O conjunto da análise e das consideraçôes supracitadas sintetiza a ideia do que se chamou de 'o gozo privado da política pública'.

Considera-se necessário checar futuramente as seguintes hipóteses levantadas no decorrer deste trabalho:

1. Se a EMBRATUR se tornará agência ou empresa de serviço social autônomo, bem como se isso se dará após a construção do prédio sede do Instituto;

2. O modo como se dará o processo de (des)valoração do preço do espaço nas áreas em proximidade aos municípios categorizados e regióes turísticas pertencentes ao 
MAPA, diante dos investimentos no setor turístico; e,

3. Se o MTur é o mecanismo estatal da privatização dos terrenos da União e, portanto, da terra pública, atribuindo a ela o sentido de uso turístico, e a transformando em mercadoria hegemonicamente operada pelo capital privado;

Espera-se ter contribuído ao debate acerca das políticas públicas do turismo nacional, nesse momento do governo de Michel Temer após o golpe ${ }^{16}$. O objetivo maior é tecer um movimento para se fazer políticas públicas para quem delas necessita, e não para quem, através delas, opera um negócio.

Este texto nasce e se encerra apresentando mais perguntas do que respostas. Procurou-se suscintamente apontar algumas direçôes para se chegar ao que, de modo mais amarrado e preciso, formará o corpo da tese que em breve será defendida.

\section{BIBLIOGRAFIA}

BRASIL. Ministério do Planejamento, Orçamento e Gestão. Secretaria de Planejamento e Investimentos Estratégicos - SPI. ESTUDO DA DIMENSÁO TERRITORIAL PARA O PLANEJAMENTO. Brasília: MP, 2008. Disponível em: <http://bibliotecadigital.seplan. planejamento.gov.br/handle/iditem/404 >. Acesso em: 22 jun. 2018.

. Ministério do Turismo. Mapa do Turismo Brasileiro. Brasília: MTur, 2013a.

$2013 b$.

Ministério do Turismo. Plano Nacional de Turismo 2013-2016. Brasília: MTur,

. Ministério do Turismo. Programa de Regionalização do Turismo - Diretrizes. Brasília: MTur, 2013c.

Ministério do Turismo. Mapa do Turismo Brasileiro. Brasília: MTur, 2016. Disponível em: $\quad$ http://www.turismo.gov.br/images/pdf/mapa turismo brasileiro jul 2016.pdf - Acesso em 15 ago. 2018.

Ministério do Turismo. Mapa do Turismo Brasileiro. Brasília: MTur, 2017a. Disponível em: http://www.regionalizacao.turismo.gov.br/images/pdf/mtur mapa turismo brasilei 2017 virtual 14 02.pdf-Acesso em: 30 jun. 2018.

. Ministério do Turismo. Programa BRASIL + TURISMO, 2017b. Disponível em: http://www.turismo.gov.br/brasilmaisturismo/ - Acesso em 15 ago. 2018.

. Ministério do Turismo. Cartilha: Categorização dos Municípios das Regióes

Turísticas do Mapa do Turismo Brasileiro. Brasília: MTur, 2018. Disponível em: http:// www.regionalizacao.turismo.gov.br/images/pdf/PerguntasRespostasCategorizacao2018.pdf - Acesso em: 30 jun. 2018b. 
. Portaria no 39, de 10 de março de 2017. Brasília: D.O.U. Diário Oficial da União, pp. 62-70, Seção 1, no 51, de 15 de março de 2017c. Disponível em: http://pesquisa. in.gov.br/imprensa/jsp/visualiza/index.jsp?data $=15 / 03 / 2017$ \&jornal=1 \&pagina=62 \&totalArquivos=112. Acesso em 15 ago. 2018.

Portaria Interministerial no 113, de 04 de maio de 2017. Brasília: D.O.U. Diário Oficial da União, pag. 68, Seção 1, no 86, de 8 de maio de 2017d. Disponível em: $\quad$ http://pesquisa.in.gov.br/imprensa/jsp/visualiza/index.jsp?data=08/05/2017\&jor$\underline{\text { nal=1 \&pagina }=68 \text { \&totalArquivos=128 }}$. Acesso em 15 ago. 2018.

CARLOS, Ana Fani Alessandri. A condiçáo espacial. São Paulo: Contexto, 2011.

CRUZ, Rita de Cássia Ariza da. Políticas públicas de turismo no Brasil: território usado, território negligenciado. Geosul, Florianópolis, v. 20, n. 40, p 27 - 43, julho - dezembro 2005. Disponível em: https://periodicos.ufsc.br/index.php/geosu\%201/article/view/13234 - Acesso 03 jul. 2018.

GARCIA, Rangel Lima. O BRASIL QUE VIVE(RE)MOS. São Paulo, PUC-SP, 2012. 169 p. Dissertação (Mestrado em Geografia)

- Valor e lugar diante do planejamento estatal e do mercado de terras no Brasil - democratizando aspectos da recente estratégia brasileira. In: Org: Ingrid Sarti e Glauber Cardoso Carvalho. Anais do XV FoMerco - Fórum Universitário Mercosul. Rio de Janeiro: FoMerco, 2015.

LEMOS, Clara C. Planejamento do turismo em âmbito federal: uma análise dos instrumentos utilizados e dos investimentos no setor. Rev. Adm. Pública - Rio de Janeiro 47 (6): 1401-427, nov./dez. 2013.

MARANHÃO, Christiano H. da S. A trajetória histórica da institucionalização do turismo no Brasil. Revista de Turismo Contemporâneo - RTC, Natal, v. 5, n. 2, p. 238-259, jul./ dez. 2017.

MOREIRA, Ruy. O MOVIMENTO OPERÁRIO E A QUESTÃO CIDADE-CAMPO NO BRASIL, Estudo sobre Sociedade e Espaço. Petrópolis: Vozes, 1985.

Contexto, 2006. PARA ONDE VAI O PENSAMENTO GEOGRÁFICO? Campinas:

Espaço da Mais-Valia Absoluta e Espaço da Mais Valia-Relativa, Revista Terra Livre, São Paulo, Ano 27, Vol. 1, n.36, p. 45-68, AGB - Associação dos Geógrafos Brasileiros, 2011.

Recebido para publicação em maio de 2018

Aceito para publicação em junho de 2018 